\title{
Dispersal and development of Marenzelleria spp. (Polychaeta, Spionidae) populations in NW Europe and The Netherlands
}

\author{
Karel Essink \\ Rijkswaterstaat, National Institute for Coastal and Marine Management/RIKZ, \\ P.O. Box 207, 9750 AE Haren, The Netherlands
}

\begin{abstract}
The North American spionid polychaete Marenzelleria cf, wireni was first recorded in the North Sea by Scotland in 1982. Marenzelleria cf. viridis was first found in the Baltic Sea in 1985. Tentative routes of dispersal since then are presented in this paper. In the Netherlands, a biological monitoring programme has revealed populations of $M$. cf. wireni in the Ems estuary, Wadden Sed, and in the SW Netherlands. In the Dollard (Ems estuary) a large population has developed $\left(2000-3000\right.$ individuals $\mathrm{m}^{-2} ; 8-16 \mathrm{~g}$ ash-free dry weight $\mathrm{m}^{2}$ ). Since the introduction, the macrozoobenthic community has changed from being dominated (by biomass) by bivalves, to domination by polychdetes. Recently, a similar population started to develop at Balgzand (western Dutch Wadden Sea).
\end{abstract}

\section{INTRODUCTION}

The first records of the North American spionid polychaete Marenzelleria are from 1982 (Forth estuary, Scotland; McLusky et al., 1993) and 1993 (Ems estuary, The Netherlands; Essink \& Kleef, 1988). These records were considered to represent independent introductions on opposite sides of the North Sea (Essink \& Kleef, 1993). These authors, on the basis of the time sequence of the various first records in North Sea coastal waters and estuaries as well as in the Baltic Sea, constructed tentative routes of dispersal (Fig. 1 in Essink \& Kleef, 1993), the Forth estuary being the starting point for dispersal along the Scottish and English coasts of the North Sea, and the Ems estuary being the starting point for dispersal along Dutch, German and Danish coasts and even the coastal waters of the Baltic Sea. So far, all populations discovered around the North Sea and in the Baltic Sea have been described as Marenzelleria viridis.

\section{THE IDENTITY OF MARENZELLERIA IN NW EUROPE}

Within the framework of a broadly orientated research program (for overview of results see Essink \& Schöttler, 1997) German scientists tried to explain certain differences observed between Baltic Sea (e.g. Darss-Zingst Bodden) and North Sea (Ems estuary, Weser estuary) populations. They demonstrated morphological (Bick \& Zettler, 1997) as well as reproductional (Bochert, 1997) differences between these populations. Compar- 


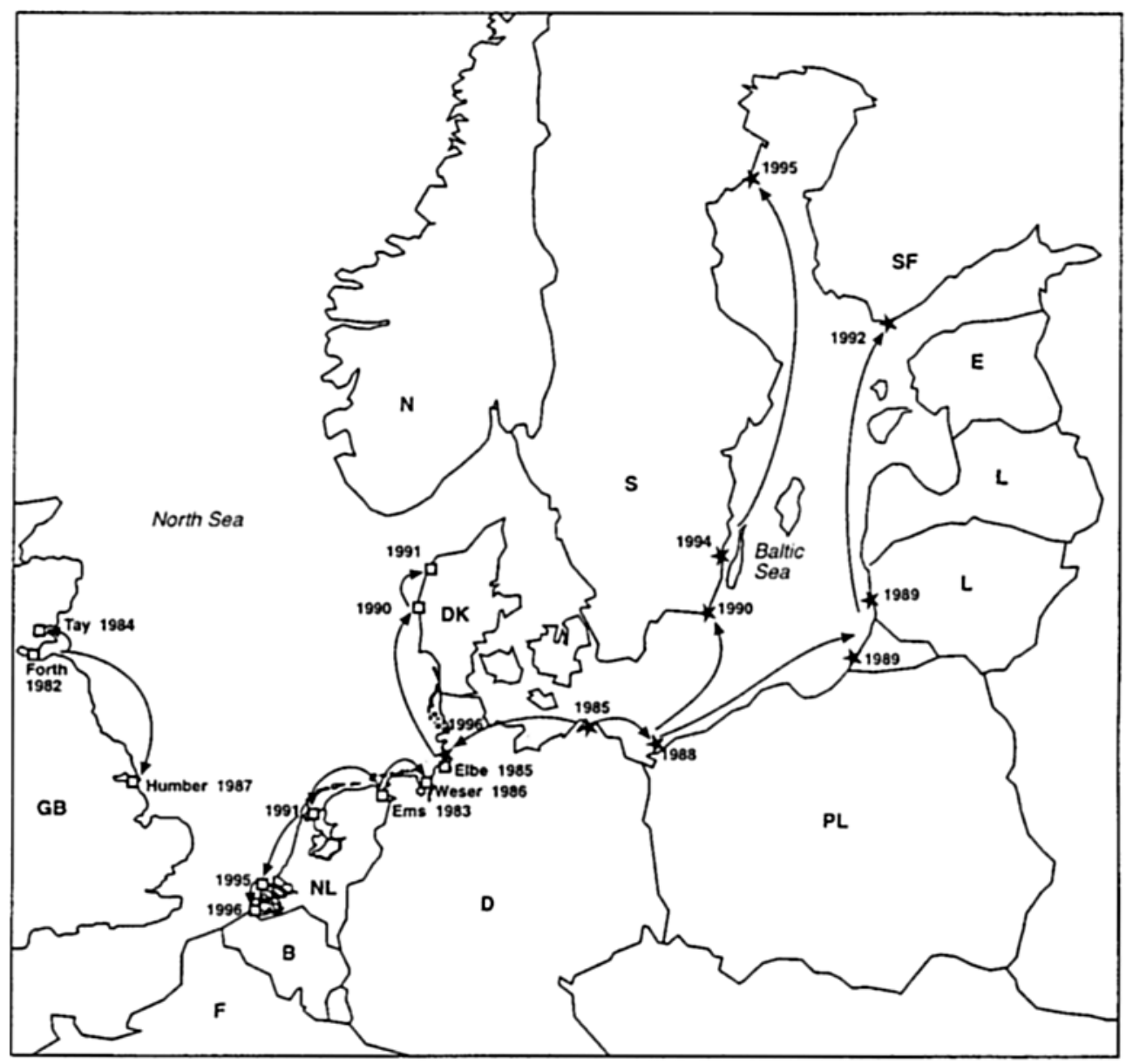

Fig. 1. Dispersal routes of Marenzelleria cf. wireni (boxes) and Marenzelleria cf. viridis (stars) in the North Sea and Baltic Sea. Adapted from Essink \& Kleef (1993) and additional information. Years indicate first local records

ative genetic investigations applying allozyme electrophoresis and DNA sequencing provided conclusive evidence of two different species of Marenzelleria being present in NW Europe (Bastrop et al., 1997). The North Sea populations were described as M. cf. wireni, and the Baltic Sea populations as $M$. cf. viridis. Parent populations of both species have been identified in several estuarine and coastal waters of NW America. In addition, the possibility exists that the observations of $M$. cf. wireni in North Sea estuaries and coastal waters are due to range expansion of either arctic populations and/or a cryptic North Sea population (for details see Bastrop et al., 1997). 


\section{DISPERSAL IN NW EUROPE}

With the knowledge now available, the tentative dispersal map once suggested by Essink \& Kleef (1993) has to be changed (Fig. 1). Now, three independent sites of introduction have to be considered:

1. M. cf. wireni-Forth estuary, Scotland (1982)

2. M. cf. wireni - Ems estuary, The Netherlands (1983)

3. M. cf. viridis - Darss-Zingst Bodden, Germany (1985)

Along the western North Sea shores, no further records of $M$. cf. wireni have been reported since 1987 (cf. Eno et al., 1997). On the eastern shores of the North Sea, $M$. cf. wireni dispersed further southward to the coastal waters of the SW Netherlands and the Western Scheldt estuary (J. Craeymeersch, personal communication). In the Baltic Sea, during the $1990 \mathrm{~s}, M$. cf. viridis expanded its range to the North along the east coast of Sweden up to the Bothnian Bay (ICES, 1997; S. Smith, personal communication). In 1996, some specimens from the oligohaline reach of the Elbe estuary were identified as M. cf. viridis (Bick \& Zettler, 1997), making the Elbe estuary the first North Sea 'home' for both M. cf. viridis and M. cf. wireni. These specimens of $M$. cf. viridis in the Elbe estuary may have originated from the Baltic Sea, as individuals have also been found recently in the middle of the Kiel Canal between the Baltic Sea and the Elbe (H. Rumohr, personal communication).

\section{POPULATIONS IN THE NETHERLANDS}

After the first find of $M$. cf. wireni in the Ems estuary a significant population developed in the Dollard, a brackish embayment in the inner part of the Ems estuary (Essink \& Kleef, 1993; Essink et al., 1998). In sandy silt sediments a few thousand individuals occur per square metre. Muddy sediments high in the intertidal zone seem to act

Table 1. Populations of Marenzelleria cf. wireni in the Netherlands with year of first record and maximum density observed since. Ad. = adults; juv. = juveniles. Populations as indicated in Fig. 2

\begin{tabular}{|c|c|c|c|}
\hline Population & Year & Density $\left(n \mathrm{~m}^{-2}\right)$ & Source \\
\hline \multirow[t]{2}{*}{ Dollard } & \multirow[t]{2}{*}{1983} & Ad: : $2000-3000$ & Essink \& Kleef, 1993 \\
\hline & & Juv.: $\quad 130000$ & \\
\hline Groningen & 1994 & 52 & RWS $\cdots$ \\
\hline Piet Scheve & 1994 & 145 & RWS * * \\
\hline Western Wadden Sea & 1994 & 117 & RWS * \\
\hline Balgzand & 1989 & 2155 & R. Dekker, unpublished \\
\hline Voordelta* & 1995 & 40 & J. Craeymeersch, unpublished \\
\hline Western Scheldt* & 1995 & p.m. & Ysebaert et al., 1997; unpublished \\
\hline Rotterdam Waterway ${ }^{*}$ & 1997 & 67 & J. Craeymeersch, unpublished \\
\hline
\end{tabular}




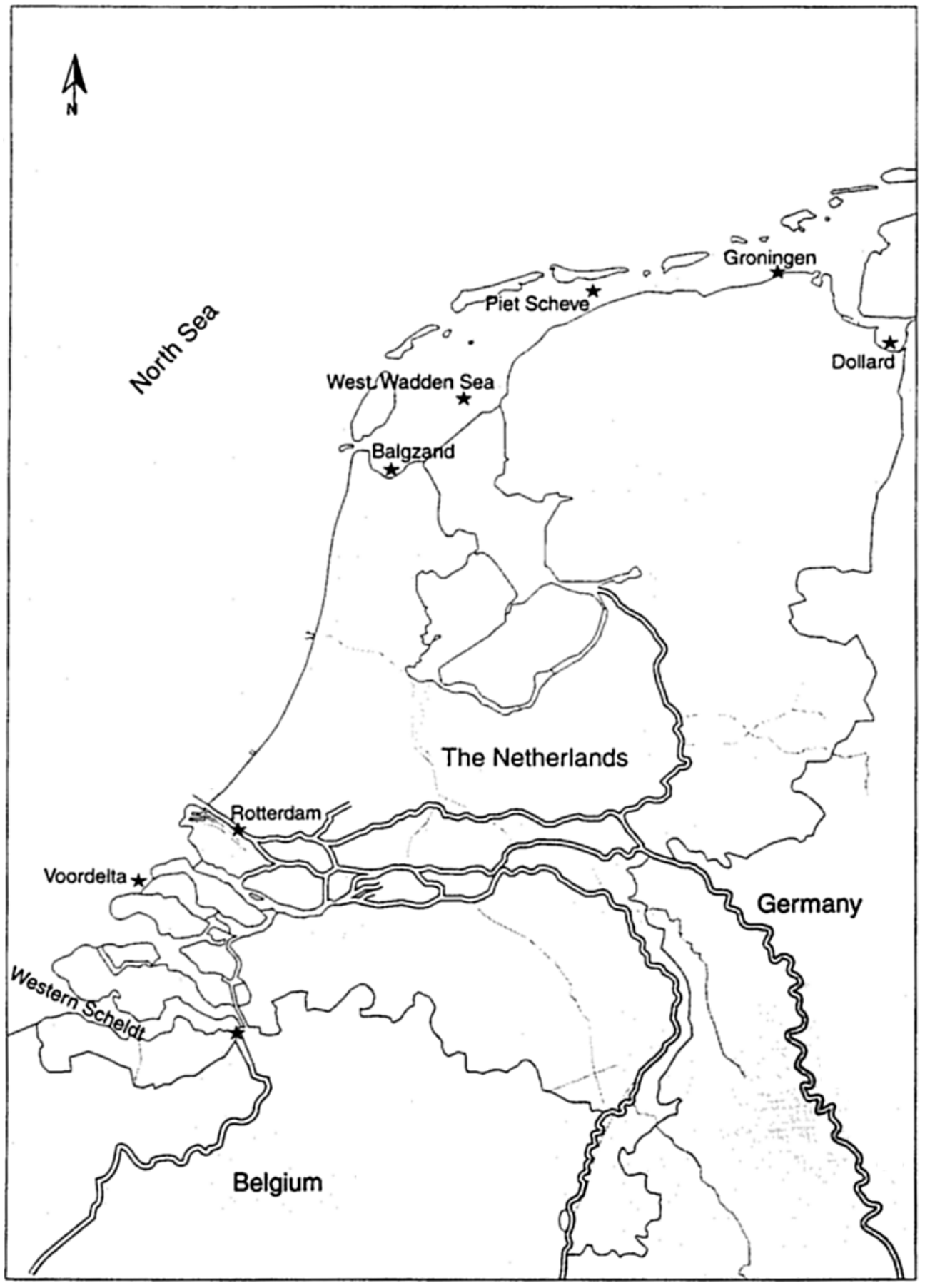

Fig. 2. Map of the Netherlands with location of known intertidal and shallow subtidal populations of Marenzelleria cf. wireni in the Wadden Sea and SW Netherlands. See also Table 1 
as a nursery area, with more than a hundred thousand juveniles per square metre (Essink \& Kleef, 1993).

Other intertidal as well as shallow subtidal populations, viz. in the Dutch Wadden Sea and in the waters of the SW Netherlands, were less successful. Here, densities were observed of a few to 150 individuals $\mathrm{m}^{-2}$ (Table 1; Fig. 2). An exception, however, is the population at Balgzand intertidal flats (western Dutch Wadden Sea), where since 1997 a population of ca. 2000 individuals $\mathrm{m}^{-2}$ has been present (Table 1).

\section{DEVELOPMENT OF THE DOLLARD POPULATION}

After its first appearance in 1983, M. cf. wireni showed a dramatic development, attaining a biomass of 8-16 $\mathrm{g}$ ash-free dry weight (AFDW) $\mathrm{m}^{-2}$ in the years 1989-1994 (Essink et al., 1998). This alien species caused a major turnover of the macrozoobenthic community. Whereas before its introduction (1977-82) polychaetes made up only $24 \%$ of the total biomass, and bivalves predominated $(64 \%)$, after the establishment of $M$. cf. wireni (1986-1994) polychaetes represented 58\%, with no more than $25 \%$ bivalves. In the Dollard, polychaetes have certainly been taking over (cf. Reise, 1982). Juvenile plaice (Pleuronectes platessa) and flounder (Platichtys flesus\} have been found to exploit the new food source, although the amphipod Corophium volutator remained their staple diet (Essink \& Kleef, 1993).

\section{DISCUSSION}

At first glance, an expansion of $M$. cf. wireni from the Ems estuary in a westward direction is not very likely because of the eastward residual water transport patterns inside the Dutch Wadden Sea. Along the coast, however, a westward transport of water, and therefore of pelagic larvae, is very well possible, as was made plausible in the case of dispersal of the American Jack-knife clam Ensis directus (= E. americanus) (Essink, 1985). Ship-mediated transport, however, cannot be excluded. As a matter of fact, there have been transports of seed mussels (Mytilus edulis) fished in the eastern Dutch Wadden Sea that were seeded on culture lots in the westernmost part. Moreover, shiploads of cultured mussels are transported from the Dutch Wadden Sea to the SW Netherlands (Eastern Scheldt) to be cleansed and marketed.

During the years 1989-1994, in the Dollard a negative correlation was found between the biomass of M. cf. wireni and that of Nereis spp., suggesting a competitive interaction between these two polychaete species. As Marenzelleria is able to perform as a filter-feeder as well as as a deposit-feeder (Dauer et al., 1981), competition for food and for space may be the acting process. The correctness, however, of this suggestion will depend on the outcome of relevant experiments that are yet to be carried out.

The main reason for the successful development of $M$. cf. wireni in the Dollard may be the ability of this animal to utilize a hitherto unexploited food source. After all, the total macrozoobenthic biomass in the Dollard increased from 10-15 $\mathrm{g}^{\text {AFDW m}}{ }^{-2}$ before the introduction of $M$. cf. wireni to $15-25 \mathrm{~g} \mathrm{AFDW} \mathrm{m}^{-2}$ thereafter. This means there are question marks against the concept that ecosystems have a limited food resource ca- 
pacity. An explanation may be the assumption that an empty niche was still available and taken by the newcomer $M$. cf. wireni.

Acknowledgements. Susan Smith, Rob Dekker, Johan Craeymeersch and Tom Ysebaert are thanked for making their unpublished data available. Thanks are due to Rob Jungcurt for preparation of the figures.

\section{LITERATURE CITED}

Bastrop, R., Röhner, M., Sturmbauer, C. \& Jürss, K., 1997. Where did Marenzelleria spp. (Polychaeta: Spionidae) in Europe come from? Aquat. Ecol. 31, 119-136.

Bick, A \& Zettler, M. L., 1997. On the identity and distribution of two species of Marenzelleria (Polychaeta: Spionidae) in Europe and North America. Aquat. Ecol. 31, 137-148.

Bochert, R., 1997. Marenzelleria viridis (Polychaeta: Spionidae): a review of its reproduction. Aquat. Ecol. n, 163-175.

Dauer, D., Maybury, C. A. \& Ewing, R. M., 1981. Feeding behaviour and general ecology of several polychaetes from the Chesapeake Bay. J. Exp. Mar. Biol. Ecol. 54, 21-38.

Eno, C., Clark, R. A. \& Sanderson, W. G. (eds), 1997. Non-native species in British waters: a review and directory. Joint Nature Conservation Committee, Peterborough, $152 \mathrm{pp}$.

Essink, K., 1985. On the occurrence of the American Jack-knife clam Ensis directus (Conrad, 1843) (Bivalvia, Cultellidae) in the Dutch Wadden Sea. Basteria 50, 73-80).

Essink, K. \& Kleef, H. L., 1988. Marenzelleria viridis (Verrill, 1873) (Polychdeta: Spionidae): a new record from the Ems estuary (The Netherlands/Federal Republic of Germany). Zool. Bijdr. (Leiden) $38,1-13$.

Essink, K. \& Kleef, H. L., 1993. Distribution and life cycle of the North American spionid polychaete Marenzelleria viridis (Verrill, 1873) in the Ems estuary. Neth. J. Aquat. Ecol. 27, 237-246.

Essink, K. \& Schöttler, U., (eds), 1997. Studies on Marenzelleria spp. (Polychaeld: Spionidae). Aquat. Ecol. 31, 117-258.

Essink, K., Eppinga, J. \& Dekker, R., 1998. Long-term changes (1977-1994) in intertidal macrozoobenthos of the Dollard (Ems estuary) and effects of introduction of the North American spionid polychaete Marenzelleria cf. wireni. Senckenb. Marit. 28, 211-225.

ICES, 1997. Report of the Working Group on Introductions and Transfers of Marine Organisms, La Tremblade, France, 22-25 April 1997. ICES CM 1997/Env: 6.

McLusky, D. S., Hull, S. C. \& Elliott, M., 1993. Variations in the intertidal and subtidal macrofauna and sediments along a salinity gradient in the upper Forth Estuary. Neth. J. Aquat. Ecol. 27, 101-109.

Reise, K., 1982. Long-term changes in the macrobenthic invertebrate faund of the Wadden Sea: are polychaetes about to take over? Neth. J. Sea Res. 16, 29-36.

Ysebaert, T., Meire, P., De Block, M., De Regge, N. \& Soors, J., 1997. A first record of Marenzelleria viridis (Verrill, 1873)(Polychaeta, Spionidae) in the Schelde estuary (Belgium). Biol. Jaarb. Dodonaea 64, 1996, 176-181. 